\title{
Role of biocementation to improve mechanical properties of mortar
}

\author{
SNIGDHA P BHUTANGE ${ }^{1, *}, \mathrm{M} \mathrm{V} \mathrm{LATKAR}^{1}$ and T CHAKRABARTI ${ }^{2}$ \\ ${ }^{1}$ Civil Engineering Department, Visvesvaraya National Institute of Technology (VNIT), Nagpur 440010, India \\ ${ }^{2}$ Nagpur, India \\ e-mail: snigdhabhutange12@gmail.com; mv.latkar@gmail.com; tapan1249@gmail.com
}

MS received 16 February 2018; revised 8 August 2018; accepted 25 September 2018; published online 4 February 2019

\begin{abstract}
Biocementation or Microbially Induced Calcium Carbonate Precipitation (MICCP) is a naturally occurring green technique which involves the deposition of calcium carbonate by peculiar action of ureolytic bacteria, which improves the mechanical properties of cementitious materials. These bacteria require a protein source, a vitamin source and a carbon source for optimum growth. Urea and calcium source are necessary to carry out the ureolysis reaction to get $\mathrm{CaCO}_{3}$ depositions which fill the voids within the cementitious materials thereby improving their mechanical properties. To make the process economical, it is necessary to find out optimum concentrations of the various chemicals and ingredients used in the process. Present study aims at finding out the best possible combination of urea and protein source to carry out the MICCP process successfully. There was $22.44 \%$ increase in compressive strength and $16.62 \%$ reduction in the water absorption of experimental mortar cubes at 28 days of curing with the optimum combination of urea and protein source concentrations.
\end{abstract}

Keywords. Biocementation; MICCP; calcium carbonate; ureolysis.

\section{Introduction}

In this era most of the population is looking forward to urbanization and the construction industry has gained a supreme importance. Mortar is one of the largest and bulk consumption items in construction industry as it is used as a binding material for bricks, stones and other masonry units due to its low cost and availability. Although mortar has many advantages, it is vulnerable to deterioration, corrosion and cracks and hence loses its strength over a period of time when subjected to variable weathering actions. Remediation and repair of construction works is a very costly affair.

Various synthetic filler agents, epoxy, epoxy resins and different commercial admixtures are being used for this purpose. However, these remedies are immensely expensive and in many cases are not eco-friendly, thus there is need of some alternative green and clean technology for saving enormous structures from damage [1-3].

It is a well-known fact that calcium carbonate is most abundantly occurring mineral in nature. Various microorganisms have tendency to deposit calcium carbonate as a part of their metabolic activity. These deposits are found out to be very good binders between loose substrate

T. Chakrabarti: Formerly MPCB, Civil Engineering Department, Visvesvaraya National Institute of Technology (VNIT), Nagpur, 440010, India

*For correspondence particles and provide strength to the same as a whole structure by occupying the voids in between substrate particles. Many natural structures such as ant hills on land and coral reefs in water are best examples of calcification occurring at ambient conditions and providing them sustainability.

Microbially induced calcium carbonate precipitation (MICCP) is the utilization of this capability of microorganisms for strengthening the construction materials thereby saving a lot of money and resources in an ecofriendly and sustainable manner $[4,5]$. The technique of MICCP has been found to have high potential to remediate cracks in building materials in an environmental friendly manner and also to protect and consolidate decayed construction materials $[6,7]$.

Ammonium concentration, oxygen availability, mineralogy and soil particle size are part of the conditions that may influence ureolytic activity of the bacteria that are assessed [8]. Soil as a source of bacteria provided with nutrient rich environment, urea and a source of calcium are the main players of the process of biocementation [9].

Abo-El-Enein et al described that the incorporation of the moderately alkalophilic aerobic Sporosarcina pasteurii increase the compressive strength of cement mortar cubes by about $33 \%$ at the age of $28^{\text {th }}$ day of curing [10].

It has also been revealed in one study that the use of Bacillus sp. CT-5 bacteria in cement mortar specimen led to $40 \%$ increase in the compressive strength as compared to 
that of mortar specimen made with tap water and also about $50 \%$ reduction in the porosity [11]. In another study done by Achal et al it has been investigated that the lactose mother liquor (LML) which is a waste from dairy industry can be used to replace conventional standard nutrient media used for the growth of calcifying bacteria. Thus this study provides a more sustainable way of construction material improvement which is as good as the conventional way [12]. Charpe et al have used general soil bacteria (without isolation) which proved to be as effective as isolated cultures. The use of lentil seeds as a source of protein and sugar as a source of carbon make the process more economically viable [9].

In a study carried out by Sun-Gyu Choi, instead of using calcium chloride or other calcium salts, soluble calcium was produced by mixing eggshell with vinegar and used for the MICCP process which was just as good as that using calcium chloride [13].

The study carried out by Gomez et al extended an attention to application of MICCP from small scale laboratory tests to large scale on field construction. A large tank of $1.7 \mathrm{~m}$ diameter containing $0.7 \mathrm{~m}^{3}$ of a poorly-graded natural sand was treated with large cementation injections. Results were found out to be satisfactory even in large scale operation [14].

The following reactions given by Eq. (1) to (7) explain the sequence of processes occurring in MICCP [15].

- Initially, in the presence of urease, urea gets hydrolyzed to form carbamate and ammonia

$$
\mathrm{CO}\left(\mathrm{NH}_{2}\right)_{2}+\mathrm{H}_{2} \mathrm{O} \rightarrow \mathrm{NH}_{2} \mathrm{COOH}+\mathrm{NH}_{3}
$$

- Additional one mole of ammonia and carbonic acid are formed due to hydrolyses of carbamate

$$
\mathrm{NH}_{2} \mathrm{COOH}+\mathrm{H}_{2} \mathrm{O} \rightarrow \mathrm{NH}_{3}+\mathrm{H}_{2} \mathrm{CO}_{3}
$$

- These products subsequently form 1 mole of bicarbonate and 2 moles of ammonium and hydroxide ions, respectively.

$$
\begin{gathered}
\mathrm{H}_{2} \mathrm{CO}_{3} \rightarrow \mathrm{H}^{+}+\mathrm{HCO}_{3}^{-} \\
2 \mathrm{NH}_{3}+2 \mathrm{H}_{2} \mathrm{O} \rightarrow 2 \mathrm{NH}_{4}^{+}+2 \mathrm{OH}^{-}
\end{gathered}
$$

- The previous reactions give rise to a $\mathrm{pH}$ increase due to which the bicarbonate equilibrium is shifted and carbonate ions are formed.

$$
\begin{gathered}
\mathrm{HCO}_{3}^{-}+\mathrm{H}^{+}+2 \mathrm{NH}_{4}^{+}+2 \mathrm{OH}^{-} \\
\rightarrow \mathrm{CO}_{3}^{2-}+2 \mathrm{NH}_{4}^{+}+2 \mathrm{H}_{2} \mathrm{O}
\end{gathered}
$$

- As the cell wall of a bacterium is generally negatively charged, bacteria attract cations including $\mathrm{Ca}^{2+}$ from the environment which get deposited on their cell surface. Subsequently the $\mathrm{Ca}^{2+}$ ions react with $\mathrm{CO}_{3}{ }^{2-}$ ions, to form $\mathrm{CaCO}_{3}$ precipitation at the surface of the cell, which serves as a nucleation site [15].

$$
\begin{gathered}
\mathrm{Ca}^{2+}+\mathrm{Cell} \rightarrow \mathrm{Cell}-\mathrm{Ca}^{2+} \\
\mathrm{Cell}-\mathrm{Ca}^{2+}+\mathrm{CO}_{3}^{2-} \rightarrow \text { Cell }-\mathrm{CaCO}_{3} \downarrow
\end{gathered}
$$

Present study was done by using cost effective ingredients such as sugar as a source of carbon instead of D-glucose and lentil seeds (Lens culinaris) powder as a source of protein instead of expensive peptone. Lentil seeds contains $25 \mathrm{~g}$ proteins/100 g dry weight [16].

\section{Materials and methods}

\subsection{Preparation of experimental solution}

For the present study, rhizospheric soil was used as a source of bacteria instead of pure culture to make the process cost effective. The quantity of soil taken was $200 \mathrm{~g} / \mathrm{l}$ of water. Meat extract as a vitamin source and sugar as a carbon source were added in amounts $3 \mathrm{~g} / 1$ and $0.5 \mathrm{~g} / 1$, respectively. Commercial D-glucose was replaced by sugar as a carbon source to reduce the cost. As a protein source for bacteria, commercially used peptone was replaced by lentil seed powder as its cost is about 53 times less than peptone. Lentil seed powder was added in variable amounts for different sets of experiments to find out the optimum concentration. The resulting mixture was then incubated for $24 \mathrm{~h}$ at $37^{\circ} \mathrm{C}$. After incubation, the optical density of the resulting mixture was measured at $600 \mathrm{~nm}$ in spectrophotometer, which was found out to be 0.856 . This value of optical density indicates sufficient cell biomass in the experimental solution. The supernatant of the experimental solution was then separated from the soil. Urea and gypsum (as a calcium source) were then added to the solution to carry out the hydrolysis of urea by the microbial mass in the experimental solution to form $\mathrm{CaCO}_{3}$ precipitation. The amount of gypsum (calcium sulfate) used was double the urea concentration as calculated from the stoichiometry of the chemical reaction.

\subsection{Preparation of control 1 solution}

Control 1 solution was prepared to study the effects of added chemicals and other ingredients on the mechanical properties of mortar in the absence of bacteria. This was made exactly like experimental solution but without adding soil.

\subsection{Measurement of $\mathrm{pH}$}

Since $\mathrm{pH}$ is an important parameter that indicates different stages in a chemical reaction, the $\mathrm{pH}$ of the experimental 
Table 1. $\mathrm{pH}$ of the experimental solution at various experimental stages.

\begin{tabular}{lr}
\hline Experimental stages & $\mathrm{pH}$ range \\
\hline Before incubation & $6.8-7.4$ \\
After incubation & $4.7-5.2$ \\
After adding urea and gypsum & $8.5-9.5$ \\
\hline
\end{tabular}

solution was measured at different stages of experiment. The values of $\mathrm{pH}$ of the experimental solution at different stages are as shown in table 1.

\subsection{Sand and cement}

For the present study, locally available natural river sand was used confirming to IS 383 (1970) [17] of zone II having specific gravity of 2.60. Ordinary Portland cement (OPC) confirming to IS 12269 (2013) [18] was used. The chemical composition of OPC is given in table 2.

\subsection{Specimen preparation}

The standard ratio of cement to sand i.e., 1:3 was maintained; also water to cement ratio was maintained to 0.42 throughout the study. Control, control 1 and experimental specimens of standard size $70.7 \mathrm{~mm} \times 70.7 \mathrm{~mm} \times$ $70.7 \mathrm{~mm}$ were cast as per IS 4031 (part 6) 1988 [19]. Cylinders of size $100 \mathrm{~mm} \times 200 \mathrm{~mm}$ were prepared for rapid chloride permeability test (RCPT) as per ASTM C1202 [20]. All specimens were compacted well in vibration machine. The specimens were demolded after $24 \mathrm{~h}$ of cast and kept for curing.

\subsection{Design of experiment}

Control specimens were made up of cement, sand and water. Control 1 specimens were made up of cement, sand and control 1 solution. Experimental specimens were made up of cement, sand and experimental solution. The

Table 2. Chemical components of ordinary Portland cement.

\begin{tabular}{lcr}
\hline Material & Components & \multicolumn{1}{c}{$\%$} \\
\hline Ordinary Portland Cement & Silicon dioxide $\left(\mathrm{SiO}_{2}\right)$ & 18.89 \\
& Aluminum oxide $\left(\mathrm{Al}_{2} \mathrm{O}_{3}\right)$ & 6.35 \\
& Ferric oxide $\left(\mathrm{FeO}_{3}\right)$ & 3.87 \\
& Calcium oxide $(\mathrm{CaO})$ & 62.23 \\
& Magnesium oxide $(\mathrm{MgO})$ & 2.30 \\
& Potassium oxide $\left(\mathrm{K}_{2} \mathrm{O}\right)$ & 0.22 \\
Sodium dioxide $\left(\mathrm{Na}_{2} \mathrm{O}\right)$ & 0.17 \\
& Sulphur trioxide $\left(\mathrm{SO}_{3}\right)$ & 0.83 \\
& Loss of ignition $(\mathrm{LOI})$ & 4.21 \\
& Total & 99.07 \\
\hline
\end{tabular}

Table 3. Various combinations of concentrations of lentil seed powder and urea employed in the study.

\begin{tabular}{lcc}
\hline Combinations & Lentil seed powder g/l & Urea g/l \\
\hline Combination 1 & 5 & 1 \\
Combination 2 & 10 & 1 \\
Combination 3 & 5 & 2 \\
Combination 4 & 10 & 2 \\
Combination 5 & 5 & 4 \\
Combination 6 & 10 & 4 \\
\hline
\end{tabular}

concentration of lentil seed powder as a protein source and concentration of urea were kept variable to suggest best optimal combination of their concentrations. For every combination of concentration of urea and lentil seed powder, six cubes for each 3,7 and 28 days were cast. Table 3 shows six different combinations of lentil seed powder and urea. Three cubes of every combination were used for compressive strength test and rest of the three cubes of were used for water absorption test for curing period of 3,7 and 28 days.

\subsection{Curing conditions}

The control specimens were cured in water. Control 1 and experimental specimens were cured in curing solution composed of sugar $0.5 \mathrm{~g} / \mathrm{l}$, urea $1 \mathrm{~g} / \mathrm{l}$ and gypsum $2 \mathrm{~g} / \mathrm{l}$ at room temperature i.e. $27 \pm 2{ }^{\circ} \mathrm{C}$ for 3,7 and 28 days. This was done to ensure that sufficient substrate, calcium source and carbon source are available for the bacteria to carry out the calcium carbonate formation reactions. Table 4 shows the compositions of curing solutions used for control 1 and experimental specimens.

\section{Results}

\subsection{Compressive strength test}

IS 4031 (part 6) 1988 [19] was followed for the compressive strength testing of control, control 1 and experimental specimens of all six combinations mentioned in table 3 at

Table 4. Compositions of curing solutions used for control 1 and experimental specimens.

\begin{tabular}{lcccc}
\hline $\begin{array}{c}\text { Sl. } \\
\text { no. }\end{array}$ & $\begin{array}{c}\text { Type of } \\
\text { specimen }\end{array}$ & $\begin{array}{c}\text { Sugar g/l in } \\
\text { water }\end{array}$ & $\begin{array}{c}\text { Urea g/l in } \\
\text { water }\end{array}$ & $\begin{array}{c}\text { Gypsum g/l } \\
\text { in water }\end{array}$ \\
\hline 1 & $\begin{array}{c}\text { Control } \\
\text { specimens } \\
\text { Control 1 } \\
\text { specimens }\end{array}$ & 0 & 0 & 0 \\
2 & 0.5 & 1 & 2 \\
\hline & $\begin{array}{c}\text { Experimental } \\
\text { specimens }\end{array}$ & 0.5 & 1 & 2 \\
\hline
\end{tabular}


Table 5. Average compressive strength of control, control and experimental specimens and \% increase in average compressive strength of experimental specimens as compared to control specimens at $3^{\text {rd }}, 7^{\text {th }}$ and $28^{\text {th }}$ day of curing.

\begin{tabular}{|c|c|c|c|c|c|c|c|c|c|c|c|c|c|c|c|}
\hline \multirow[b]{2}{*}{ Combinations } & \multicolumn{3}{|c|}{$\begin{array}{l}\text { Average compressive } \\
\text { strength of control } \\
\text { specimens }\left(\mathrm{N} / \mathrm{mm}^{2}\right) \\
\text { or } \mathrm{MPa}\end{array}$} & \multicolumn{3}{|c|}{$\begin{array}{l}\text { Average compressive } \\
\text { strength of control } 1 \\
\text { specimens }\left(\mathrm{N} / \mathrm{mm}^{2}\right) \\
\text { or } \mathrm{MPa}\end{array}$} & \multicolumn{3}{|c|}{$\begin{array}{l}\text { Average compressive } \\
\text { strength of } \\
\text { experimental } \\
\text { specimens }\left(\mathrm{N} / \mathrm{mm}^{2}\right) \\
\text { or } \mathrm{MPa}\end{array}$} & \multicolumn{3}{|c|}{$\begin{array}{l}p \text { value (As per } \\
\text { ANOVA) }\end{array}$} & \multicolumn{3}{|c|}{$\begin{array}{c}\% \text { Increase in } \\
\text { compressive strength }\end{array}$} \\
\hline & $\begin{array}{c}3 \\
\text { Days }\end{array}$ & $\begin{array}{c}7 \\
\text { Days }\end{array}$ & $\begin{array}{c}28 \\
\text { Days }\end{array}$ & $\begin{array}{c}3 \\
\text { Days }\end{array}$ & $\begin{array}{c}7 \\
\text { Days }\end{array}$ & $\begin{array}{c}28 \\
\text { Days }\end{array}$ & $\begin{array}{c}3 \\
\text { Days }\end{array}$ & $\begin{array}{c}7 \\
\text { Days }\end{array}$ & $\begin{array}{c}28 \\
\text { Days }\end{array}$ & $\begin{array}{c}3 \\
\text { Days }\end{array}$ & $\begin{array}{c}7 \\
\text { Days }\end{array}$ & $\begin{array}{c}28 \\
\text { Days }\end{array}$ & $\begin{array}{c}3 \\
\text { Days }\end{array}$ & $\begin{array}{c}7 \\
\text { Days }\end{array}$ & $\begin{array}{c}28 \\
\text { Days }\end{array}$ \\
\hline Combination 1 & 32.14 & 34.68 & 44.01 & 30.68 & 34.41 & 41.35 & 33.61 & 36.01 & 45.35 & 0.0034 & 0.0003 & 0.020 & 4.56 & 3.85 & 3.03 \\
\hline Combination 2 & 32.28 & 35.34 & 45.35 & 32.01 & 34.01 & 41.35 & 33.34 & 36.68 & 46.15 & & & & 3.31 & 3.77 & 1.76 \\
\hline Combination 3 & 24.41 & 30.68 & 33.88 & 23.67 & 27.34 & 31.08 & 27.34 & 35.34 & 41.48 & & & & 12.02 & 15.22 & 22.44 \\
\hline Combination 4 & 29.48 & 30.01 & 36.01 & 27.01 & 30.01 & 34.01 & 32.54 & 35.48 & 43.35 & & & & 10.41 & 18.22 & 20.37 \\
\hline Combination 5 & 28.68 & 33.34 & 37.34 & 29.34 & 32.28 & 36.14 & 32.14 & 38.68 & 44.15 & & & & 12.09 & 16.00 & 18.21 \\
\hline Combination 6 & 31.48 & 34.54 & 37.61 & 30.28 & 33.61 & 37.48 & 34.14 & 38.14 & 44.68 & & & & 8.47 & 10.42 & 18.79 \\
\hline
\end{tabular}

the curing age of 3,7 and 28 days, respectively. Table 5 shows the average compressive strengths of control, control 1 and experimental specimens and \% increase in average compressive strength of experimental specimens as compared to control specimens at the curing age of 3, 7 and 28 days, respectively for all the six combinations. The combination 3 i.e., $2 \mathrm{~g} / \mathrm{l}$ of urea and $5 \mathrm{~g} / \mathrm{l}$ of lentil seeds powder gave best results.

\subsection{Water absorption test}

Water absorption test was performed on all types of specimens as per ASTM C140-11a [21]. The specimens, after curing periods of 3,7 and 28 days were drawn from respective curing solutions and wiped with a dry cloth. The saturated weights of mortar specimens were taken. The specimens were then kept in oven at a temperature range of $105^{\circ} \mathrm{C}$ to $110^{\circ} \mathrm{C}$ for $24 \mathrm{~h}$. After $24 \mathrm{~h}$ of oven drying, dry weights of specimens were noted down. The water absorption was found out from difference between initial and final weights. Combination 3 was found to give best results i.e., $11.77 \%, 13.77 \%$ and $16.62 \%$ reduction at $3^{\text {rd }}$, $7^{\text {th }}$ and $28^{\text {th }}$ days of curing, respectively (refer table 6).
The increase in compressive strength and decrease in water absorption in experimental specimens are due to calcium carbonate precipitation. This is due to the action of ureolytic bacteria which hydrolyse urea thus producing carbonate ions. When gypsum (calcium sulfate) is added as calcium source, calcium carbonate is formed which being insoluble gets deposited in the pores of matrix of mortar specimens. This, in turn, causes increase in compressive strength and decrease in water absorption (refer to chemical reactions given in section 1). This is clear in the SEM images presented in figure 2. It was also observed that there was not much difference in the compressive strength and water absorption of control and control 1 specimens. This indicates that the chemicals and ingredients added other than bacteria do not have any effect on the mechanical properties of the mortar.

\subsection{Statistical analysis}

The data for compressive strength and water absorption was analyzed by Analysis of Variance (ANOVA). The $p$ value for all the sets of experiments was found to be less than

Table 6. Percent reduction in water absorption at $3^{\text {rd }}, 7^{\text {th }}$ and $28^{\text {th }}$ day of curing.

\begin{tabular}{|c|c|c|c|c|c|c|c|c|c|c|c|c|c|c|c|}
\hline \multirow[b]{2}{*}{ Combinations } & \multicolumn{3}{|c|}{$\begin{array}{l}\% \text { Water absorption } \\
\text { of control specimens }\end{array}$} & \multicolumn{3}{|c|}{$\begin{array}{c}\% \text { Water absorption } \\
\text { of control } 1 \\
\text { specimens }\end{array}$} & \multicolumn{3}{|c|}{$\begin{array}{c}\% \text { Water absorption } \\
\text { of experimental } \\
\text { specimens }\end{array}$} & \multicolumn{3}{|c|}{$\begin{array}{c}p \text { value (As per } \\
\text { ANOVA) }\end{array}$} & \multicolumn{3}{|c|}{$\begin{array}{c}\% \text { Reduction in water } \\
\text { absorption }\end{array}$} \\
\hline & $\begin{array}{c}3 \\
\text { Days }\end{array}$ & $\begin{array}{c}7 \\
\text { Days }\end{array}$ & $\begin{array}{c}28 \\
\text { Days }\end{array}$ & $\begin{array}{c}3 \\
\text { Days }\end{array}$ & $\begin{array}{c}7 \\
\text { Days }\end{array}$ & $\begin{array}{c}28 \\
\text { Days }\end{array}$ & $\begin{array}{c}3 \\
\text { Days }\end{array}$ & $\begin{array}{c}7 \\
\text { Days }\end{array}$ & $\begin{array}{c}28 \\
\text { Days }\end{array}$ & $\begin{array}{c}3 \\
\text { Days }\end{array}$ & $\begin{array}{c}7 \\
\text { Days }\end{array}$ & $\begin{array}{c}28 \\
\text { Days }\end{array}$ & $\begin{array}{c}3 \\
\text { Days }\end{array}$ & $\begin{array}{c}7 \\
\text { Days }\end{array}$ & $\begin{array}{c}28 \\
\text { Days }\end{array}$ \\
\hline Combination 1 & 5.78 & 5.88 & 4.83 & 5.76 & 5.83 & 4.82 & 5.75 & 5.88 & 4.74 & 0.0008 & 0.003 & 0.0001 & 0.50 & 0.00 & 1.87 \\
\hline Combination 2 & 5.88 & 5.83 & 4.89 & 5.87 & 5.75 & 4.82 & 5.80 & 5.75 & 4.87 & & & & 1.26 & 1.38 & 0.37 \\
\hline Combination 3 & 5.85 & 5.70 & 4.88 & 5.58 & 5.29 & 4.65 & 5.16 & 4.92 & 4.07 & & & & 11.77 & 13.77 & 16.62 \\
\hline Combination 4 & 5.83 & 5.61 & 4.80 & 5.57 & 5.42 & 4.59 & 5.20 & 4.86 & 4.06 & & & & 10.87 & 13.44 & 15.50 \\
\hline Combination 5 & 5.87 & 5.63 & 4.86 & 5.40 & 5.06 & 4.75 & 5.25 & 5.00 & 3.98 & & & & 10.53 & 11.11 & 18.15 \\
\hline Combination 6 & 5.78 & 5.88 & 4.83 & 5.63 & 5.07 & 4.19 & 5.26 & 5.00 & 3.99 & & & & 9.03 & 14.89 & 17.36 \\
\hline
\end{tabular}


0.05 . This shows that there is a significant variation amongst the samples (see tables 5 and 6 ).

\subsection{Durability tests}

3.4a Chloride, sulfate and carbonation tests: Since combination 3 was found out to be the best combination, chloride, sulfate and carbonation tests were conducted for all types of mortar specimens made by using combination 3. According to IS 456; 2000 allowable chloride content for mortar containing non-embedded metal is $3 \mathrm{~kg} / \mathrm{m}^{3}$ [22]. The chloride concentration was found out in extracted experimental sample by Argentometric method and was $0.02 \mathrm{~kg} / \mathrm{m}^{3}$ which is well within the limit. The sulfate concentration of the extracted experimental sample was obtained by turbidimetric method according to IS 3025 (part 24) 1986 [23]. The soluble sulfate concentration of the experimental sample was $15.76 \mathrm{mg} / \mathrm{l}$. This is also within the limit, i.e., $400 \mathrm{mg} / \mathrm{l}$ as per IS 456:2000. For the carbonation test, phenolphthalein solution was sprayed on a freshly exposed surface of the control and experimental specimens [24]. A pink colour was obtained in control as well as experimental specimens indicating that sufficient $\mathrm{Ca}(\mathrm{OH})_{2}$ is present (refer to figure 1). This indicates that both the specimens were not much carbonated. These tests results indicate that the mortar prepared using experimental solution is durable and resistant to weathering and does not cause additional carbonation due to MICCP reaction

3.4b Rapid chloride permeability test (RCPT): Rapid chloride permeability test for best combination i.e., combination 3 was performed to determine ability of mortar specimens to resist the chloride ion penetration and their electrical conductivities. Rapid chloride permeability test was performed according to ASTM C1202 (ASTM C1202, 2017) [20]. Control and experimental specimens were tested for RCPT. The average values of charge passed for control and experimental specimens were found out to be $1220 \mathrm{C}$ and $458 \mathrm{C}$, respectively. The permeability class for
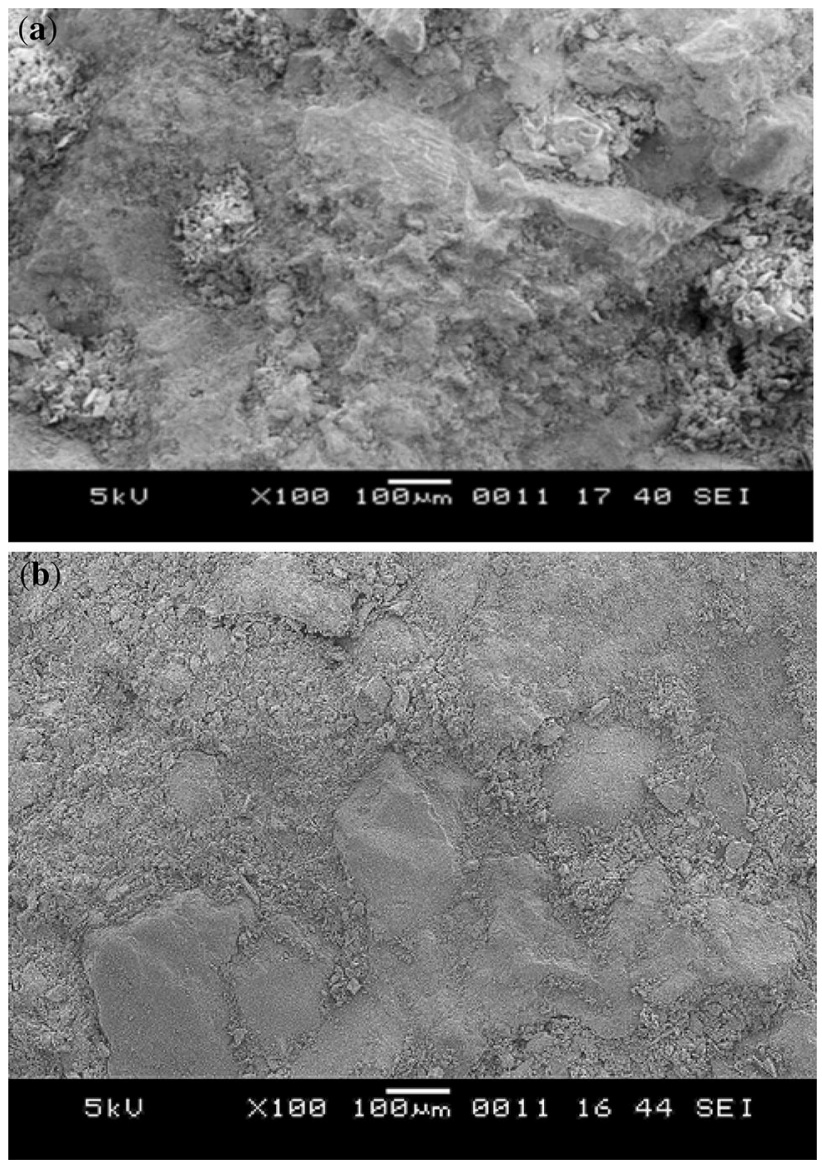

Figure 2. SEM images of (a) control specimen and (b) experimental specimen.

control specimens was low and for experimental specimens was very low according to ASTM C1202.

\subsection{Scanning Electron Microscopy (SEM) analysis}

To study the effect of biocementation, the 28 days specimens of both control and experimental were examined
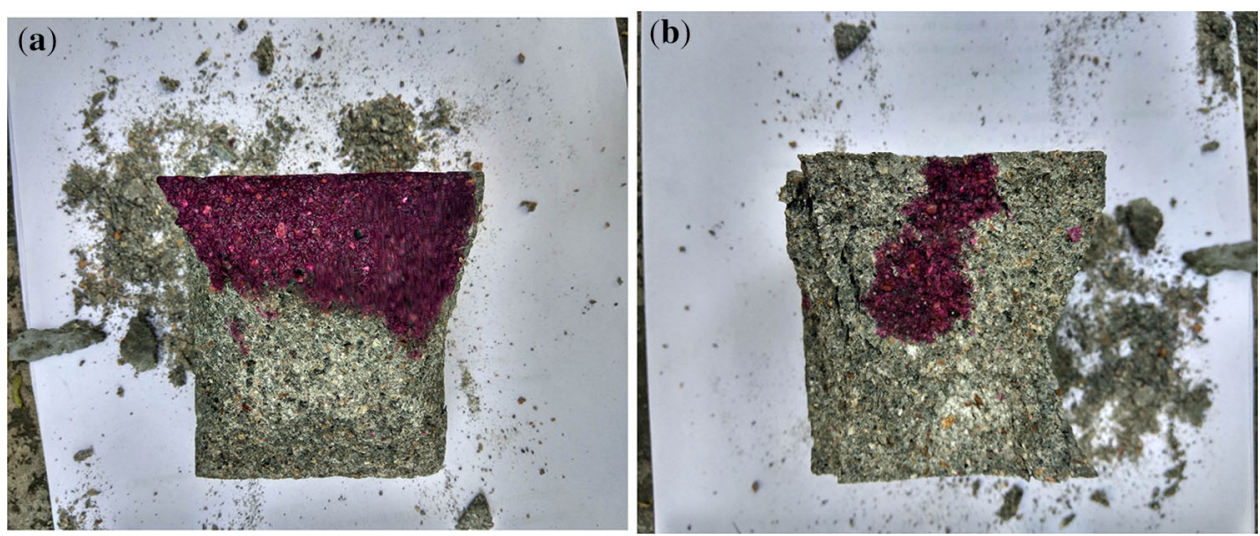

Figure 1. Carbonation test on (a) control specimen and (b) experimental specimen using phenolphthalein. 
(a)

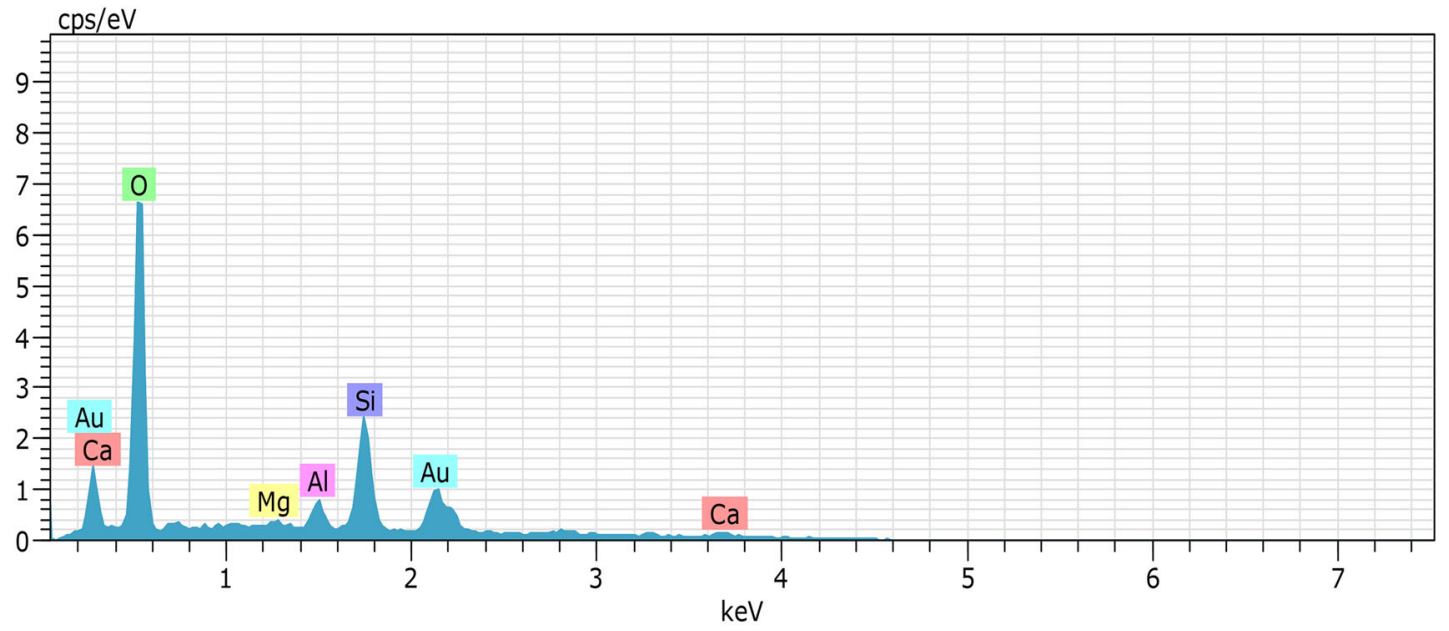

(b)

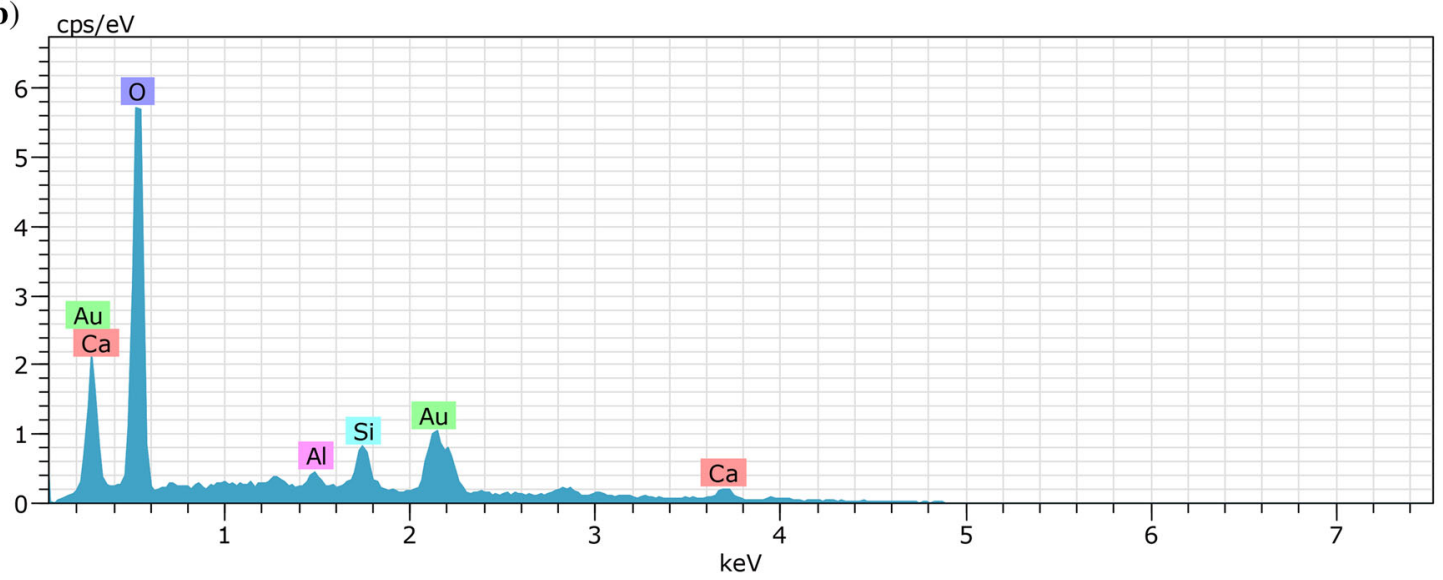

Figure 3. EDX analysis of (a) control specimen and (b) experimental specimen.

under scanning electron microscope (JSM- 6380A). On comparison of the SEM images of control and experimental specimens, it was observed that the void spaces seen in the control specimen were not seen in the experimental specimen. The Scanning Electron Micrographs are shown in figure 2 .

\subsection{Energy dispersive X-ray (EDX) analysis}

EDX analysis was done to confirm the presence of calcium carbonate mineral in the matrix of both control and experimental specimens. Figure $3 \mathrm{a}, \mathrm{b}$ show the results of EDX analysis for control and experimental specimens, respectively. The amount of calcium is clearly more in experimental specimen than in control specimen which may be because of $\mathrm{CaCO}_{3}$ deposition by bacteria in experimental specimen.

\section{$3.7 X$-ray diffraction (XRD) analysis}

The control and experimental specimens were analyzed by $\mathrm{XRD}$ to find out the type of crystalline forms (vaterite, aragonite and calcite) of the calcium carbonate crystals. Using an XPERT-PRO diffractometer system, the XRDspectra were obtained with $\mathrm{Cu}$ anode (40 kV and $45 \mathrm{~mA}$ ). The specimens were crushed to an average particle size of less than 10 microns. The XRD patterns of both specimens were obtained as shown in figure $4 a, b$, by scanning specimens by $2 \theta$ value of 10 to 99 degrees. The experimental specimen showed more number of peaks of vaterite, aragonite and calcite crystals than control specimen. This may be due to calcium carbonate formation in experimental specimen's matrix due to MICCP reaction by ureolytic bacteria.

\section{Discussion}

This study aimed to find out optimum concentrations of the two crucially important ingredients i.e., urea and protein source to carry out the MICCP reaction successfully by using low cost ingredients as mentioned in section 2.1. Table 5 shows the percent increase in compressive strength of experimental specimens in comparison with control specimens for all six combinations of concentrations of 
(a)
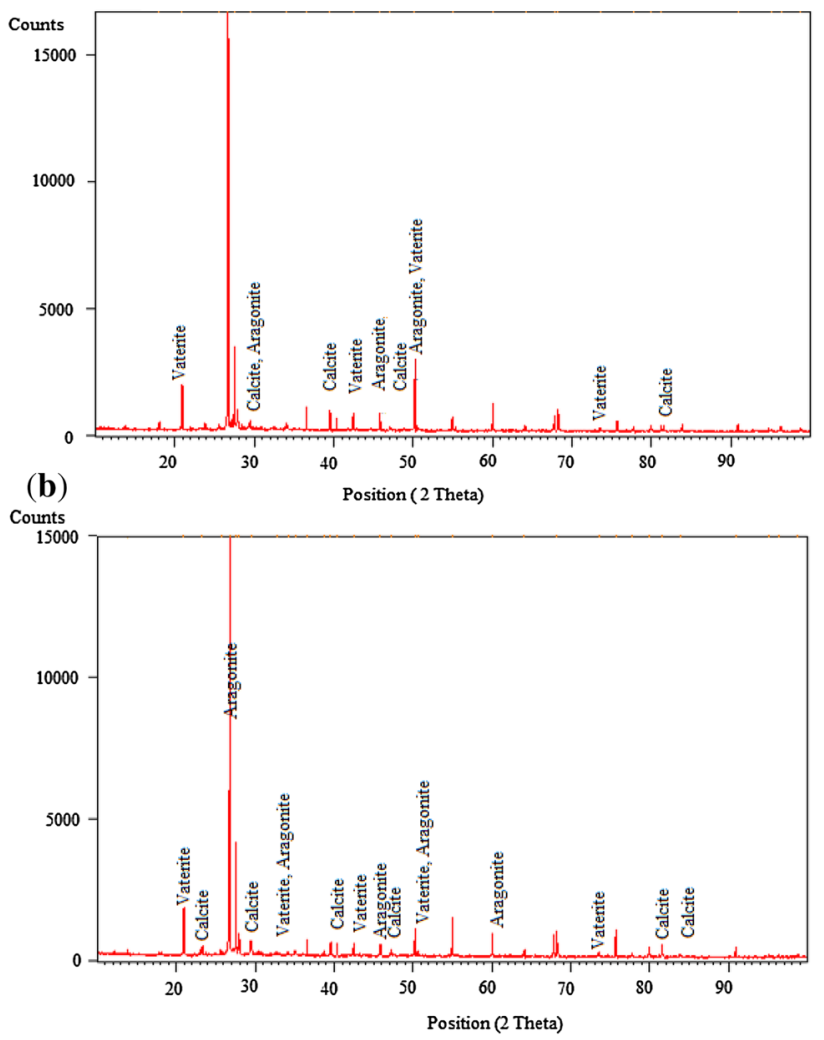

Figure 4. XRD graphs of (a) control specimen and (b) experimental specimen.

urea and lentil seeds powder. The results for water absorption are depicted in table 6 . The results show that combination 3 having $2 \mathrm{~g} / \mathrm{l}$ of urea and $5 \mathrm{~g} / \mathrm{l}$ of lentil seeds powder gave best improvement in compressive strength as well as in water absorption than other higher concentrations. Combination 3 showed $12.02 \%, 15.22 \%$ and $22.44 \%$ increase in compressive strength and $11.77 \%, 13.77 \%$ and $16.62 \%$ reduction in water absorption on $3^{\text {rd }}, 7^{\text {th }}$ and $28^{\text {th }}$ days of curing, respectively. But when an attempt was made to further minimize the concentration of urea to $1 \mathrm{~g} / \mathrm{l}$, both the combination 1 and combination 2 showed no significant change in compressive strength and water absorption. This shows that urea as a substrate was not sufficient in concentration below $2 \mathrm{~g} / 1$ (combinations 1 and 2) for carrying out successful MICCP reaction. As far as combinations 4, 5 and 6 are concerned, though there is a significant improvement in mechanical properties, the concentrations of lentil seed powder and urea are higher as compared to combination 3 . Hence it can be inferred that combination 3 seems to be economically best amongst all these combinations.

All these findings are supported by the results of SEM, EDX and XRD tests. Durability tests were performed on the experimental sample and the results of these tests showed that the experimental mortar sample is durable and resistant to weathering.

\section{Conclusion}

In this era, where there is a rapid increase in the demand of construction materials, MICCP or biocementation has been proved to be most promising and novel technique to maintain sustainability in an ecofriendly manner. Various studies are underway to make use of biocementation to strengthen structures and increase their durability. From the present study, it can be concluded that biocementation using experimental solution having $2 \mathrm{~g} / \mathrm{l}$ of urea, and $5 \mathrm{~g} / \mathrm{l}$ of lentil seed powder is better for strength enhancement as compared to other combinations of various concentrations tested. Future research is needed to replace meat extract by some other vitamin source to further reduce the cost of experimental solution. Also, studies with different calcium sources (other than gypsum) can be done.

\section{References}

[1] Arunachalam K D, Sathyanarayanan K S, Darshan B S and Raja R B 2010 Studies on the characterisation of Biosealant properties of Bacillus sphaericus. Int. J. Eng. Sci. Technol. 2: 270-277

[2] Ramakrishnan V, Panchalan R K and Bang S S 2005 Improvement of concrete durability by bacterial precipitation. In: International conference on fracture

[3] Jonkers H M and Schlangen E 2009 A two component bacteria-based self-healing concrete. Concrete Repair, Rehabilitation and Retrofitting, II: 119-120

[4] Kashyap V N and Radhakrishna 2013 A study on effect of bacteria on cement composites. Int. J. Res. Eng. Technol. 356-360

[5] Vempada S R, Reddy S S P, Rao M V S and Sasikala C 2011 Strength Enhancement of Cement Mortar using Microorganisms-An Experimental Study. Int. J. Earth Sci. Eng. 4: 933-936

[6] Jagadeesha Kumar B G, Prabhakara R and Pushpa H 2013 Effect of Bacterial Calcite Precipitation on Compressive Strength of Mortar Cubes. Int. J. Eng. Adv. Technol. 2: 486-491

[7] Jagadeesha Kumar B G, Prabhakara R and Pushpa H 2013 Bio mineralisation of calcium carbonate by different bacterial strains and their application. Int. J. Adv. Eng. Technol. 6: 202-213

[8] Umar M, Kassim K A, Tiong K and Chiet P 2016 Biological process of soil improvement in civil engineering: A review. J. Rock Mech. Geotech. Eng. 8: 767-774. https://doi.org/10. 1016/j.jrmge.2016.02.004

[9] Charpe A U, Latkar M V and Chakrabarti T 2017 Microbially assisted cementation-A biotechnological approach to improve mechanical properties of cement. Constr. Build. Mater. 135: 472-476. https://doi.org/10.1016/j.conbuildmat. 2017.01.017

[10] Abo-el-enein S A, Ali A H and Talkhan F N 2013 Application of microbial biocementation to improve the physicomechanical properties of cement mortar. HBRC J. 9: 36-40. https://doi.org/10.1016/j.hbrcj.2012.10.004

[11] Achal V, Mukerjee A and Reddy M S 2013 Biogenic treatment improves the durability and remediates the cracks of 
concrete structures. Constr. Build. Mater. 48:1-5. https://doi. org/10.1016/j.conbuildmat.2013.06.061

[12] Achal V, Mukherjee A, Basu P C and Reddy M S 2009 Lactose mother liquor as an alternative nutrient source for microbial concrete production by Sporosarcina pasteurii. J. Ind. Microbiol. Biotechnol. 36: 433-438. https://doi.org/10. 1007/s10295-008-0514-7

[13] Choi S, Wu Sand and Chu J 2016 Biocementation for Sand Using an Eggshell as Calcium Source. ASCE 142: 2-5. https://doi.org/10.1061/(asce)gt.1943-5606.0001534

[14] Gomez M G, Dejong J T, Anderson C M, Nelson D C and Graddy C M 2016 Large scale biocementation improvement of sands. Geotechnical and Structural Engineering Congress 941: 941-949

[15] Talaiekhozan A, Keyvanfar A, Shafaghat A, Andalib R, Majid M Z A and Fulazzaky M A 2014 A Review of Self-healing Concrete Research Development. J. Environ. Treat. Tech. 2: 1-11

[16] Bhatty R S, Slinkard A E and Sosulski F W 1976 Chemical composition and protein characterstics of lentils. Can. J. Plant Sci. 794: 787-794
[17] Bureau of Indian Standard IS 3831970 Specification for Coarse and Fine Aggregate From Natural Sources for Concrete, New Delhi, India

[18] Bureau of Indian Standard IS 122692013 Ordinary Portland Cement 53 grade - Specifications

[19] Bureau of Indian Standard IS 4031 (part 6) 1988 Methods of physical tests for hydraulic cement

[20] ASTM C1202 2017 Standard test methods for Electrical Indication of concrete's Ability to Resist Chloride, 1-8. https://doi.org/10.1520/c1202-12.2

[21] ASTM C140 2012 Standard test methods for sampling and testing concrete masonary units and related units, 1-17. https://doi.org/10.1520/c0140-11a

[22] Bureau of Indian Standard IS 4562000 Plain and reinforced concrete-code of practice

[23] Bureau of Indian Standard IS 3025 (part 24) 1986 Method of sampling and test (Physical and chemical) for water and wastewater part 24: sulphates

[24] RILEM, Measurement of hardened concrete carbonation depth, CPC 181986, 435-440 